THE TENSILE STRENGTHS OF THE COPPER ALUMINUM ALI,OYS

BY B. E. CURRY AND SAMUEL H. WOODS

This work was begun in order to establish the relation between the constitution of the aluminum bronzes and their tensile strengths. About twenty years ago, Tetmajer ${ }^{1}$ pub- $^{-}$ lished data on this subject. His work was handicapped seriously by an incomplete knowledge of the internal constitution of these alloys and by the impure aluminum obtainable at that time. Since then we have been able to obtain very pure aluminum and we now know about the constitution of these alloys.

Aside from the results of Tetmajer we have only incomplete data on this subject. Others have made a greater or less number of individual tests without any very definite knowledge of the internal structure.

\title{
The Equilibrium Diagram
}

In Fig. I the equilibrium diagram for the copper aluminum series is shown. The coordinates are temperature and percentage composition. The lines in the diagram mark the occurrence of some physical or chemical change. The upper full line or liquidus represents the temperatures above which the alloys are completely melted. The line just below the liquidus or the solidus line represents the temperatures below which the alloys are completely solid. Between these lines melt and crystals exist together. The lines below the solidus represent the temperatures at which some chemical clrange takes place.

In the diagram the field designated as $\alpha$ represents the concentration and the temperature over which pure $\alpha$-crystals are stable under equilibrium conditions. The crystals are composed of a solid solution of aluminum in copper. With

1 Tetmajer: Mitteilungen der Materialpsrïfungsanstalt IX Heft. Methoden und Resultate des Untersuchung des Aluminums und seiner Abkömminge. 
more than 9I percent copper there is but one form of crystallization.

$\beta, \gamma, \delta, \epsilon$ and $\eta$ also are other series of solid solutions, each having a definite crystal form. The $\eta$-series is formed by the solution of copper in aluminum. The limits of this field are very narrow when determined from chill-cast alloys. The effect of annealing is very marked over this range. The only compound, $\mathrm{CuAl}_{2}$, occurs at 53.7 percent copper.

The fields which are designated as $\alpha+\beta, \beta+\gamma$, etc., represent the concentrations and temperatures over which two

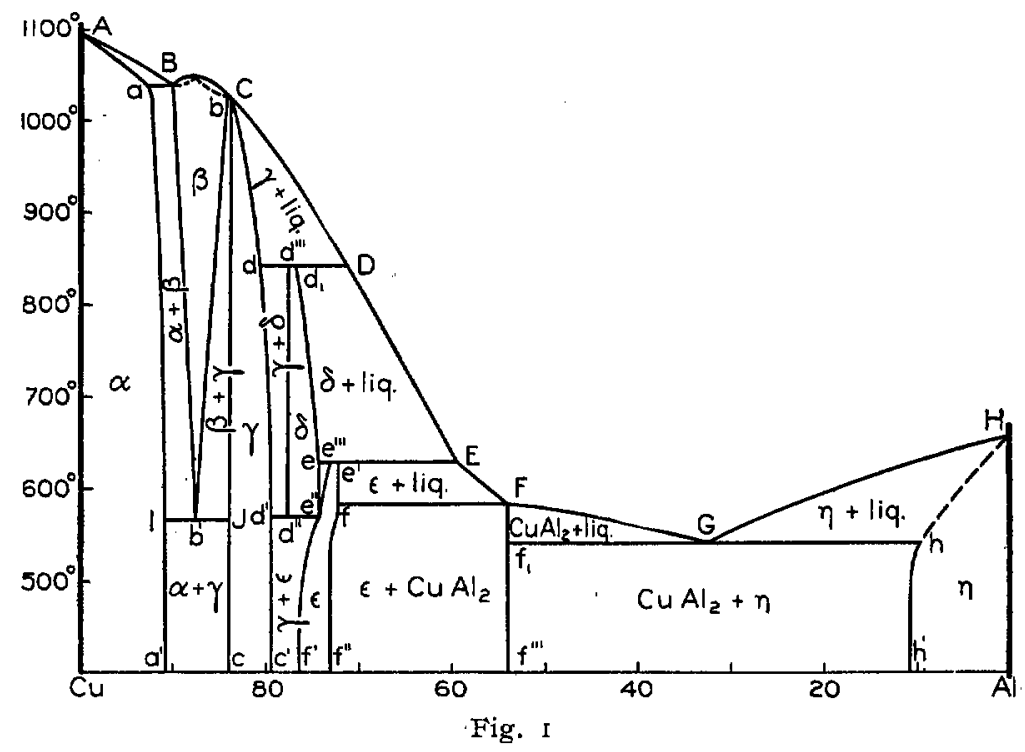

crystalline formations exist together. A field of this sort occurs between any two successive phases.

There are some chemical changes in this series of alloys which are caused by temperature changes. For example, when an 89 percent melt begins to solidify, $\beta$-crystals separate from the mother liquor. These continue to separate as the temperature drops. When the dotted line or solidus is reached the melt freezes completely and the mass is conposed of pure $\beta$-crystals. As the temperature drops still further the $\beta$ crystals begin to break down into $\alpha$. Then over a considerable 
temperature $\alpha$ - and $\beta$-crystals exist together. At $566^{\circ}$ the $\beta$-crystals break down completely to form $\alpha$-and $\gamma$-crystals. The $\beta$-phase does not appear below $566^{\circ}$ under equilibrium conditions. If an 86 percent copper alloy be followed as it cools, changes occur very much as they do in an 89 percent alloy excepting that the $\beta$-crystals break down partially to form $\gamma$ crystals at the higher temperature. At $566^{\circ}$ the $\beta$-crystals change over completely to the $\alpha$ - and $\gamma$-form. In general all changes in the solid alloys take place most rapidly at the higher temperatures. At ordinary temperatures the reaction rate is practically negligible.

Because of this slow rate at which internal changes take place at ordinary temperatures, an alloy may be heated to a given temperature, and this temperature maintained until equilibrium is established, and then if cooled very rapidly those conditions will remain fixed at ordinary temperatures. If an 88 percent alloy be heated to $700^{\circ}$ it will, under equilibrium conditions, be composed of pure $\beta$-crystals. If quenched quickly in water from this temperature the $\beta$-crystals do not have time to change over into $\alpha$-and $\gamma$-crystals, and at ordinary temperature the alloy retains the same crystalline structure it had at $700^{\circ}$. If allowed to cool more slowly, this alloy undergoes a structural change at $566^{\circ}$. If one wishes to determine the strength of a pure $\beta$-alloy an 88 percent alloy, for example, may be annealed at any temperature falling within the $\beta$-field until equilibrium is reached and then quenched rapidly. This method is of very general application.

The alloys with a copper content falling between 25 percent and 86 percent are too brittle to be of any technical value. This report is concerned only with the $\alpha, \alpha+\beta, \beta, \beta+\gamma$, $\alpha+\gamma, \eta$ and $\eta+\mathrm{CuAl}_{2}$ alloys.

The complete diagram is discussed in a separate paper. ${ }^{1}$

Artificial Acheson graphite was used in making the moulds for the test pieces. This material was first made use of for this purpose by Shepherd and Upton ${ }^{2}$ in their investi-

${ }^{1}$ Journ. Phys. Chem., rI, 425 (I907).

'Ibid., 9, 44I (I905). 
gation of the bronzes. The material is almost ideal for the purpose; it is easily worked with ordinary wood-working tools and, being usually homogeneous, takes a very smooth finish.

In making the moulds most of the cutting was done with carpenter's gouges, but the grooves for the test section were finished by means of a sharp screw thread of the desired diameter. The centrifugal sprew devised by Shepherd and Upton was made use of. To obtain this the sprew cavity was cut so as to give a corkscrew shape to the sprew. Thus when the molten metal first enters the mould it is given a whirling notion. This prevents splashing which tends to entrap air. The "airtrap" in the sprew was also used. Vents leading from this trap at the grip end and a large riser at the opposite end of the mould were also provided. Very little local necking occurs in the alloys tested, and standard proportions in the test pieces were not necessary. The diameter of the test section was $3 / 8^{\prime \prime}$ and the test length $5^{\prime \prime}$. The grip ends were made $3 / 4^{\prime \prime}$ in diameter and about $2^{\prime \prime}$ long.

Very little trouble was experienced because of occluded gases or trapped air. Some of the pieces when broken showed small amounts of slag, but this was no fault of the moulds. The only difficulty which could be attributed to the moulds was the breaking of the pieces near the ends. This was found to be caused by a too sharp angle in the test piece where grip end and test section meet. This difficulty disappeared when the angle in the mould was sufficiently rounded off. If the halves of the mould were clamped too tightly, shrinking stresses were often found to develop. Best results were obtained when the halves of the mould were clamped together at the sprew end, the riser ends being held together by means of bricks placed on the floor against the sides.

Oxidation was prevented by addition of powdered charcoal and by passing illuminating gas directly into the crucible. This was found to be very effective in excluding oxygen from the melt. By observing these precautions the composition of the melt was not materially affected by oxidation and the anıunt of slag was kept at a minimum. 
A certain amount of slag and oxide is inevitable. After a test piece had been cast the remaining metal was poured into a small ingot mould and the crucible then jarred on the floor. In this manner all the slag was removed from the crucible after each melt. There was a tendency for the slag to cling to the crucible and the metal was almost always entirely free from slag or oxide as it entered the moulds.

The crucibles were made from cylinders of Acheson graphite about $4 \frac{1}{2}{ }^{\prime \prime}$ in diameter. They were turned out by chucking in a lathe and cutting with ordinary machine tools. These crucibles were entirely satisfactory in every respect except durability. No practical means were found for preventing the flames in the furnace from striking the sides of the crucible. When casting the alloys rich in copper, only i 5 to 20 pourings could be made from one crucible. With the aluminum-rich alloys many more pourings could be made before the walls burned through.

An ordinary gas furnace equipped with air blast was used for the source of heat. In this a temperature of about $1500^{\circ}$ could be obtained. After the furnace became hot the bronzes with the higher melting points could be made quickly. We made it a practice to keep the melt in the furnace the shortest practicable length of time. The time factor has much to do as regards the amount of slag and oxide formed.

The aluminum used in making these alloys was about 99.97 percent. It was presented to us by the Pittsburg Reduction Company to whom we express our thanks. The copper was the best electrolytic product. In making the aluminumrich alloys it was found practicable to melt the aluminum and then to add the copper. This method was satisfactory when the surface of the metal aluminum was free from slag and the surface of the copper was bright. Otherwise the copper did not always dissolve readily. In making the copper-rich alloys the copper was always melted first and the aluminum added to the melt. Thorough mixture of the two metals was obtained by stirring with a graphite rod.

It was early noted that when aluminum is added to molten 
copper the temperature rises from $150^{\circ}$ to $250^{\circ}$. This was first supposed to be caused by the reduction of copper oxide but this is not the reason. If a second amount of aluminum is added a similar rise in temperature is observed. The phenomena must be due to heat of solution. A like phenomenon occurs when copper is dissolved in molten tin.

All of the test-pieces were repeatedly melted. The composition was checked from time to time by analysis and in nearly every case the variation was less than one-tenth of one percent. The number of meltings did not affect the quality of the copperrich test-pieces, but after the aluminum-rich alloys were melted several times the average percent of good pieces began to drop.

It was not found necessary to heat the moulds before pouring. In most cases good pieces could be obtained by pouring into a cold mould. It was usually necessary to have the first melt somewhat hotter than the succeeding ones.

The temperature of pouring was kept as low as possible as a matter of economy of fuel, crucibles, and time. It is difficult to say definitely at what temperature any given alloy should be poured, for that is a matter requiring experience and judgment. The best copper-rich test-pieces were made by pouring at such a temperature that the metal would about half fill the riser. If poured colder than this the piece would be likely to be bad at the end. If poured much hotter the lower part of the mould would fill first, then the upper part would fill and a seam, noticeable on the outside of the piece but not apparent on the inside, would be formed. This fault was not a serious one but did not add to the appearance of the piece. This phenomenon did not appear in the aluminum-rich alloys at all. The castings obtained were as nearly perfect as could be desired and the surface in most cases was as smooth as if machined. The part of the casting corresponding to the joint in the mould showed a slight fin in most cases. This was not great enough to cause any inconvenience.

The treatment given the pieces recorded as chill-cast was as uniform as possible. The pieces were poured from about the same temperature head above their melting point. They 
were then allowed to cool sufficiently to allow handling and then quenched in water. The annealings below $5 \mathrm{Oo}^{\circ}$ were carried on in a specially constructed furnace. This was made of brick and large enough to hold about thirty pieces It was constructed to give an evenly distributed heat. The heat was supplied from two large Bunsen burners, the hot gas passing along the bottom and sides and then over the top of the enclosed muffle in which the pieces were packed.

The temperature was read by means of a pyrometer and could be kept sufficiently constant for our purpose. For the annealings above $565^{\circ}$ a coke-fired assay furnace was used. The time required at these temperatures was short and the assay furnace was very satisfactory. The temperature was observed as in the first furnace. The test-pieces were packed in a fire-clay muffle in powdered graphite. The mouth of the nuffle was closed with clay or asbestos paper. The aluminumrich alloys showed no evidence of oxidation due to annealing. There was a marked tendency for the copper-rich pieces to oxidize, and a stream of illuminating gas was passed into the muffle. At the worst, the film of oxide formed on the surface of the bronze pieces was too thin to cause any trouble. In fact the filn could be easily removed with the nail or a knife point.

The aluninum-rich alloys were given but one heat treatment; namely, annealing at $400^{\circ}$. The copper-rich pieces were given two heat treatments; Ist, annealing at $500^{\circ}$ for 2 days and $2 \mathrm{~d}$, annealing above $.565^{\circ}$ for 30 minutes. In the latter treatment the pieces were quenched from about $750^{\circ}$. The pieces annealed at or below $500^{\circ}$ were not quenched but allowed to cool in the muffle.

A few of the bronzes were cast and allowed to cool slowly in the air, protected from draughts.

\section{Testing}

Practically all of the tests were made on a Io,ooo pound Olsen machine. This machine was well adapted to our purposes because of its small size and accuracy. The cross section of the test-pieces was small and the actual breaking load was 
only in a few cases greater that Io,ooo pounds. Because of this nearly all of the pieces broke within the range of the machine.

The mechanism of this machine was worked by hand. This was found to be advantageous in a number of ways.

The method of procedure in testing was briefly as follows:

The diameters of the test-pieces were carefully measured with micrometer calipers readitı directly in thousandths of an inch. The snillest diameter was always the one recorded. The pieces were not perfectly circular but varied slightly in diameter at any one section. Three or four diameters were taken and the average of these was recorded. In some cases the fin, formed by the imperfect fitting of the halves of the mould, was filed away. This fin is not large enough, however, to affect the strength of the piece appreciably, so that the filing was generally omitted.

The records of extension were taken by means of a 6-inch drafting compass fitted with fine steel points. It would have been desirable to use an extensometer for this purpose, but none short enough was obtainable. The method finally adopted was to make a fine prick punch mark at the end of the piece uppermost in the machine, and mark the lower end by means of the point of the compass. Making these two marks exactly $5^{\prime \prime}$ apart results in a considerable saving of time of computation. It was easy to take the extensions quite accurately in this way. After the beam had been balanced with the desired load, the compass was set to coincide with both marks, and the distance thus measured was read on a steel scale divided in hundredths of an inch; with the aid of a magnifying glass, extensions were thus easily read in thousandths.

A few of the stronger pieces were broken in a 100,000 pound Riehlé machine, which has a noticeable throwback. In all the tests run on this machine, the mechanism was run at low speed, and extension readings were taken with the machine running, as the load was raised. By this means, the effect of throwback is eliminated. 
In all the tests on both machines, care was taken to have the beam floating at the time of fracture.

After the pieces were broken the halves were removed from the machine and carefully observed. The character of the fracture was recorded in every case. The final extension was obtained by measuring between the marks with the broken ends held together. Care was taken to correct for the opening left between the ends.

\section{Results}

The results of the experiments are presented in the accompanying tables, and are shown graphically on the curve sheets. While it might have been desirable to present all the extension data exactly as taken, it would also have been very cumbrous. Extension data are given for representative pieces of every composition tested.

Table I gives records of all the pieces broken, which gave tests which were considered not seriously affected by slag, air holes, or shrinkage strains. Strengths per square inch have been computed from the diameter of the smallest section, measured before testing. Ductilities are computed from the final extension, corrected by adding the initial extension as shown by the stress-strain diagrams, as described later.

Table II gives complete records of the "best" pieces. Since the highest strength obtainable by experiment is the true strength of any material, these records are representative of the various alloys.

Two corresponding sets of curves have been plotted:

Fig. 2 shows the variation of strength and ductility with composition, for the best pieces of the aluminum-rich alloys. Fig. 3 shows the same for the bronzes. The points corresponding to pure copper are taken from the data obtained by Shepherd and Upton in 1904.

Figs. 4-7 are the stress-strain diagrams. The coördinates of such a diagram are, as standardized, load per square inch, as ordinates, and extension from initial length, per inch of length as abscissae. In the present case, since all the pieces were of the same length, actual extensions were used as abscissae. 
They are all plotted in accordance with standard practice; that is, zero extension is plotted for initial load, and for the other loads; extensions reckoned from the length at initial load
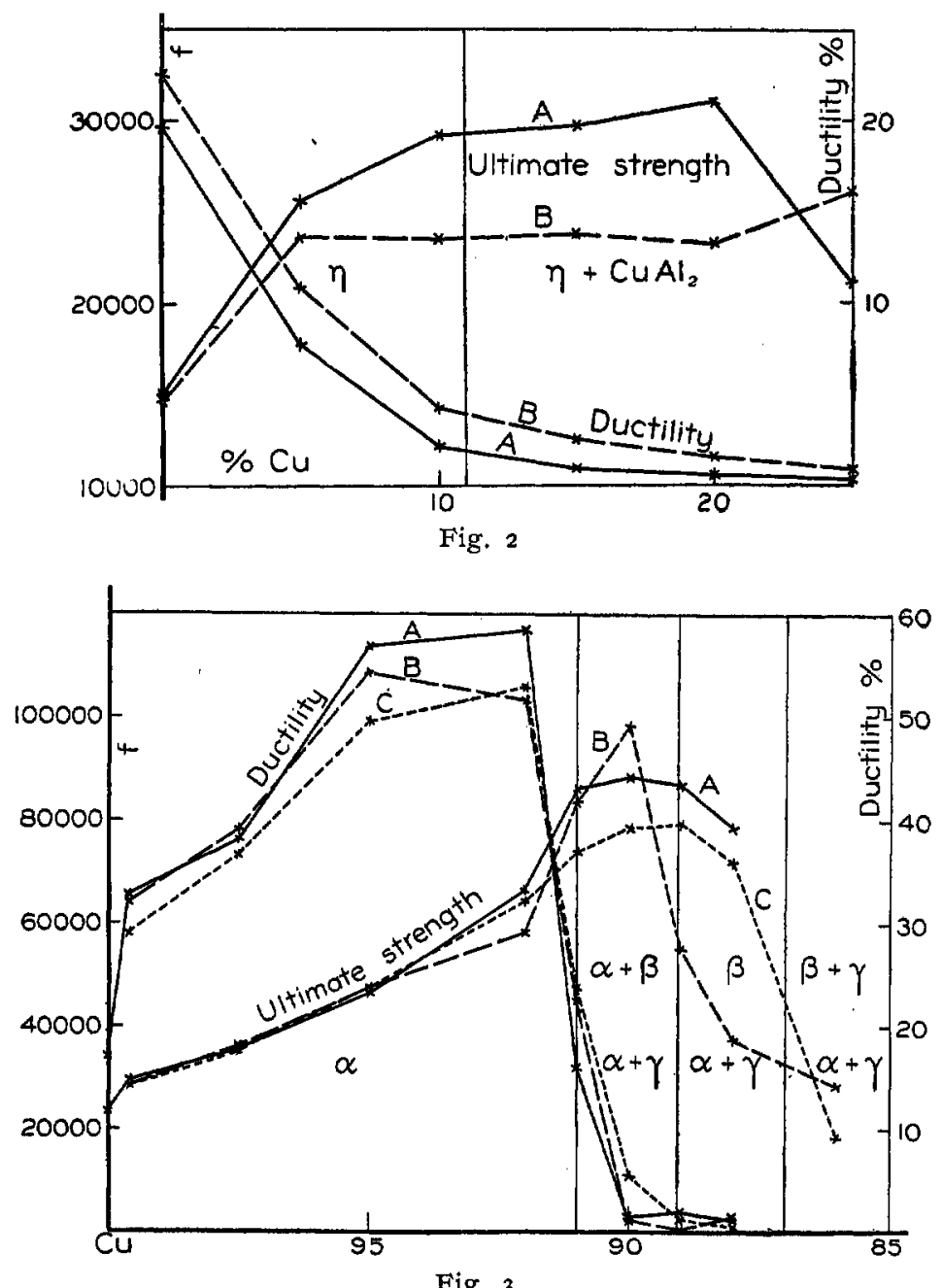

Fig. 3

are plotted. The curve is then drawn, and the intercept on the axis of abscissae noted. This intercept is the extension at the initial load, and the curve is then shifted a distance equal to 
this intercept, to the right so as to pass through the origin. In all cases the initial load was so small as to give practically no extension.

In all the curves, tables and diagrams, $A$ refers to chillcast pieces; $B$ to pieces annealed at the lower temperatures; $\mathrm{C}$ to pieces annealed above $565^{\circ}$ for 30 minutes and waterquenched; D to pieces allowed to cool in the air.

Referring to Fig. 2, both the chill-cast and annealed pieces

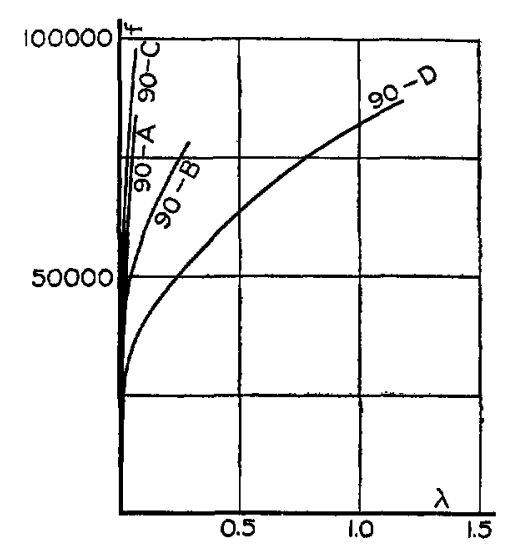

Fig. 4

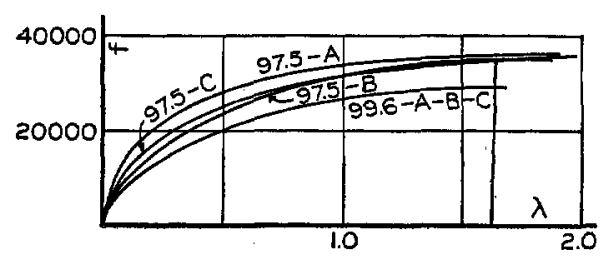

Fig. 5

show a very rapid increase in strength as we go from pure aluminum to the 5 percent alloy. For the chill-cast pieces this increase continues more gradually until we reach the maximum at 20 percent $\mathrm{Cu}$. From here there is a very marked drop to the 25 percent alloy. This may be assigned largely to a peculiarity of the very brittle alloys which we are approaching. When the metal enters the mould, it freezes at the surface, thus forming a skin. When shrinkage takes place, 
the skin already formed, being very stiff, cannot yield and a void is formed at the center. It seems almost impossible to prevent this. The annealed pieces show almost a constant strength throughout the range from 5 percent copper to 20 percent copper. A considerable rise in strength is noticed at 25 percent copper, due to the fact that the piece showed no
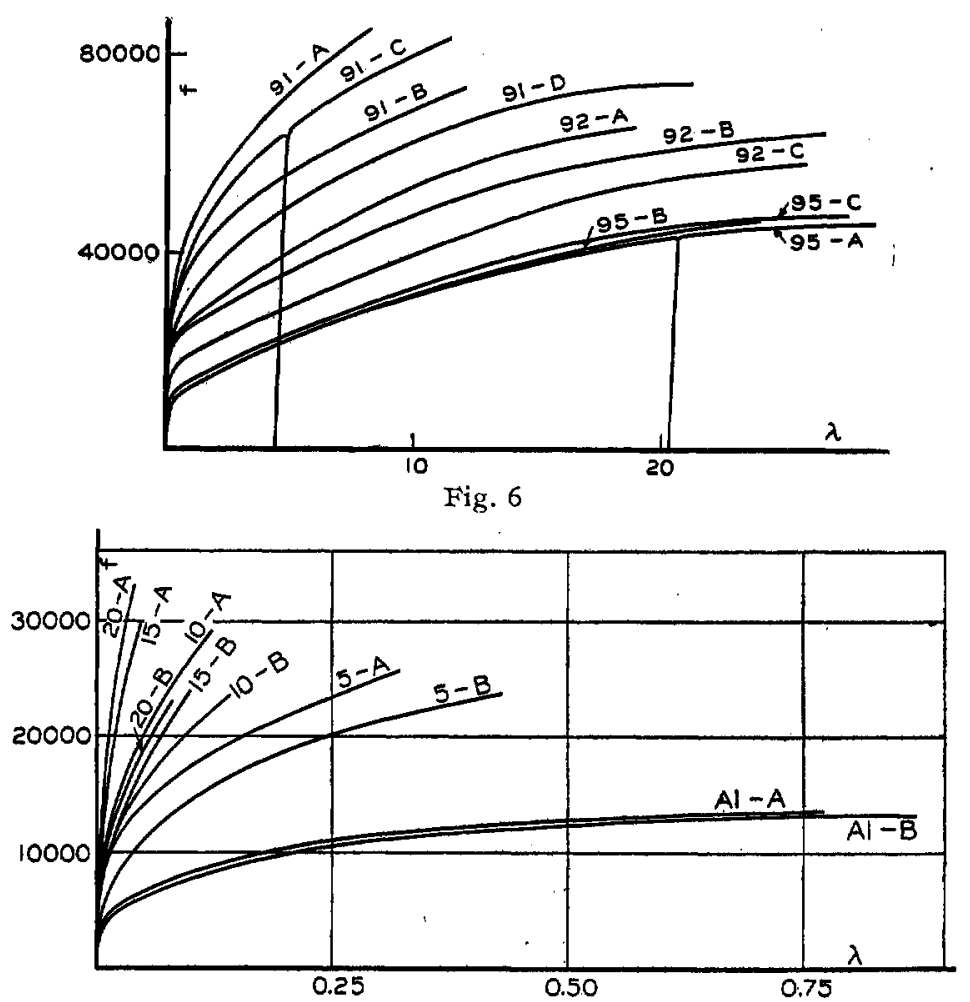

Fig. 7

signs of the void at the center, which was so noticeable in the other pieces of this composition.

The curves for ductility show a steady decrease as the copper content increases, rapid at first and then more gradual. This shows very clearly the stiffening effect of the $\mathrm{CuAl}_{2}$ crystals.

Both the strength and ductility curves show the effect of 
annealing quite markedly. For every alloy tested, barring the 25 percent, the annealing reduces strength and increases ductility. As noted before, the 25 percent copper alloys did not show shrinkage voids, so that this apparent exception to the rule is the result of the absence of these voids and not of structural change. Temperature changes do not affect or change the structure in any way except to increase the size of the crystals. The best dependable alloy is about Io percent copper. This corresponds very closely to the edge of the $\eta$ field or to the appearance of $\mathrm{CuAl}_{2}$ crystals as shown in Fig. $\mathrm{I}$. While some good tests were obtained on alloys with more than Io percent copper the pieces were by no means uniform.

In the strength curves (Fig. 3 ) there is very marked increase in strength due to small amounts of aluminum. This is due in all likelihood to two reasons; first, the aluminum removes all traces of copper oxide and produces a sound casting, and second, to the formation of an alloy. From this composition, 99.6 percent copper, the curves for all heat treatments are very nearly coincident and show a gradual rise in strength until the copper content is 92 percent. As the aluminum content is further increased, the curves rise more rapidly and continue to a maxinum with 90 percent copper. The curve beigns its rapid rise while in the $\alpha$-field but very close to the edge where $\beta$-crystals first appear, the 9 I percent copper alloy is largely made up of $\alpha$-crystals with traces of the $\beta$-phase appearing between. Chill-cast alloys with a composition lying in the $\alpha-+\beta$-region (see Fig. I) contain only these two phases as do the same alloys when annealed above $566^{\circ}$. When these same alloys are air-cooled the $\beta$ breaks down, partly at least, to form the $\alpha$ - and $\gamma$-phases. Under these conditions $\alpha$-, $\beta$ - and $\gamma$-phases are probably present. The maximum strength was found in an 89.9 percent copper chill-cast piece which broke under a load of 108,200 pounds per square inch. The strength drops slightly again at 89 percent copper and still more at 88 percent, where pure $\beta$-crystals are still present. These crystals, as shown by the fractures, are very large, even when cooled rapidly, 
The annealing has a very noticeable effect on the strength of the bronzes after we pass the 92 percent alloy. At 92 percent, the strength of the pieces annealed above $566^{\circ}$ falls considerably below that of chill-cast pieces and those annealed at $500^{\circ}$, which last run very close together. At 9 I percent, the strength of the pieces annealed above $566^{\circ}$ runs up nearly to that of the chill-cast, while that of the pieces annealed at $500^{\circ}$ is quite a little lower. At 90 percent, the chill-cast pieces have a strength intermediate between the strengths of the annealed pieces, the difference being about 10,000 pounds per square inch with those annealed above $566^{\circ}$ highest at 98,000 pounds per square inch.

At 89 percent and 88 percent, the pieces annealed at $500^{\circ}$ show about 8,000 pounds per square inch less strength than the chill-cast pieces. For these compositions, the pieces annealed above $565^{\circ}$ showed up rather more poorly. This is due to the fact that at the temperature of quenching (about $800^{\circ}$ ), these alloys soften and tend to bend. Also above $600^{\circ}$ the crystals grow very rapidly, and this causes the strength of the alloys to be greatly reduced. The 86 percent alloys were the most brittle with which we had to deal; so much so that if allowed to fall to the floor they were almost certain to break. The strengths recorded mean very little, for the pieces nearly always failed by breaking in the grips.

The variation of ductility in this series of alloys is very remarkable. As with the strength, the ductility increases very rapidly at first as aluminum is added, and then more gradually, though still quite rapidly until the 95 percent bronze is reached. It probably reaches a maximum value between 95 percent and 92 percent, at which latter point the "best" piece, chill-cast showed a slightly greater value than at 95 percent. One 95 percent specimen, annealed above $566^{\circ}$, gave 60.8 percent ductility. In passing from 92 percent to $9 \mathrm{I}$ percent the ductility drops from 57.5 percent to 16 percent and again to I.2 percent at 90 percent. This shows clearly the character of the $\beta$-crystals which are exceedingly stiff. The ductility from here remains, as far as our observations continued, very nearly constant. 
The effect of annealing on the ductility is not very marked. Chill-cast pieces and those annealed above $566^{\circ}$ run very closely together from 99.6 percent to 95 percent copper, while the pieces annealed at $500^{\circ}$ show a slightly smaller value. At 92 percent, the chill-cast pieces are the best as regards ductility, the annealed pieces showing somewhat smaller values, both close together. At 9 I percent copper, the ductility curves are dropping so rapidly that it would be safe to say only that the ductilities lie in the neighborhood of 20 percent or about $1 / 3$ the value at 92 percent. At 90 percent chill-cast pieces and those annealed above $566^{\circ} \mathrm{C}$ were very low in ductility, while those annealed at $500^{\circ} \mathrm{C}$ showed considerably more, 6-8 percent.

A few air-cooled pieces were made-90 percent and 91 percent. These show a rather marked increase in ductility over that of any other specimens of the same composition (see Tables). This gain in ductility does not reduce the strength in the 90 percent alloys, but reduces it slightly in the $9 \mathrm{I}$ percent.

From the diagram, Fig. 3, it is evident that the ductility of the $\beta$-and $\gamma$-crystals is practically zero while the $\alpha$-crystals have a higher ductility the greater the aluminum content. The ductility appears to decrease at 92 percent before any of the $\beta$ - or $\gamma$-phases has appeared. It is quite possible, however, that the falling off of the ductility with increasing aluminum content is more rapid than is shown by the diagram and that a sample with a copper content of 91.5 percent might have shown as high a ductility as that with 92 percent. No explanation can be offered at present for the fact that annealing appears to decrease the ductility. The opposite effect was observed with the copper-tin bronzes and is quite marked in the aluminum-rich bronzes. At the aluminum end of the series, the ductility of the n-crystals decreases with increasing copper content and becomes very low for $\mathrm{CuAl}_{2}$.

The tensile strength of the $\beta$ bronzes is higher than that of the $\gamma$ bronzes, while that of the $\alpha$ bronzes increases with decreasing copper content. The maximum strength does not 
come at the point where the alloy ceases to be homogeneous. The presence of the stiffer $\beta$ - or $\gamma$-crystals appears to add to the strength of the alloy: up to a certain point. A sinilar phenomenon was observed with the copper-tin bronzes. The essential feature is, however, the amount of the $\alpha$-crystals present. For this reason the effects due to annealing above and below the inversion point are not so striking as with the copper-tin bronzes. Owing to the greater intrinsic strength of the $\beta$-alloys, the maximum strength is greater for the $\alpha$ - and $\beta$-alloys than for the $\alpha$ - and $\gamma$-alloys. At the aluminum end of the series, the maximum strength occurs in the field for $r$ and $\mathrm{CuAl}_{2}$ instead of at the boundary curve.

The character of fractures in the aluminum-rich series varies from the fibrous of pure aluminum to semivitreous in the 20 percent and 25 percent copper alloys. It becomes semigranular in the 5 percent, quite granular at Io percent, crystalline at 15 percent. Pure aluminum and the 5 percent alloys generally show a cupped or irregular fracture. The io percent and i 5 percent alloys are usually quite irregular but never cupped. The 20 percent and 25 percent pieces break almost square across, the 25 percent alloy breaking very much like glass.

The bronzes show a cupped, diagonal or irregular, fibrous fracture, from pure copper to the 92 percent bronze. At 9 I percent, the fracture is semi-granular and almost straight across. In the 90 percent, two sorts of fractures are noticeable. All the pieces show a crystalline fracture, those annealed at $500^{\circ}$ showing a fairly smooth break, while those chill-cast or annealed above $565^{\circ}$ were very irregular and showed large $\beta$-crystals. The air-cooled pieces were similar to those annealed at $500^{\circ}$, except that the fracture was somewhat more irregular. The 88 percent and 89 percent pieces show a very irregular, coarsely crystalline fracture and that of the 86 percent bronze is quite vitreous.

Alloys containing 5 percent copper or less show a slight local necking. This is also true of bronzes containing 92 percent copper or more, 
The color of the aluminum-rich alloys is uniformly white. The alloys containing ro percent copper or more show a beautifully smooth surface when cast. Below this amount of copper content, the surface of the castings, while smooth, was not nearly so good. Aside from this difference in smoothness, the appearance of all the alloys of this series is the same.

The bronzes show a greater variation in respect to color. The 99.6 percent bronze is very nearly the color of pure copper but slightly lighter. The 97.5 percent copper alloy has a rich gold color with a pinkish tint. The other copper-rich bronzes have a golden color which becomes lighter as the aluminum content increases. With less than 84 percent copper the yellow color disappears.

Little needs to be said about the stress-strain diagrams. These in themselves are graphical descriptions of the behavior of the various alloys. However, for any one alloy the diagrams are of similar form regardless of the heat treatment. The yield point or elastic limit can not be easily located. This, of course, is true of any unworked metal. In a few cases after the load had been run well up it was reduced to zero and then again applied and the extension readings taken. This gives the elastic lines shown in some of the diagrams. From these lines it would be possible to compute the modulus of elasticity.

In the copper-rich alloys which have a high ductility the breaking load is really much greater than the data imply. The reduction in cross-section is considerable, due to the elongation.

In the tables, the following abbreviations have been used:

Both tables, with respect to heat treatment,

A-chill-cast,

B-for aluminum-rich alloys, annealed at $400^{\circ}$, for aluminum bronzes, annealed 2 days at $500^{\circ}$,

$\mathrm{C}$-annealed above $566^{\circ}, 30$ minutes, and quenched in water,

D-air-cooled. 
Table I, with respect to character of fracture,

G-good,

B--bad,

f.-fibrous,

gr.-granular,

cr.-crystalline,

v.--vitreous,

ox.--oxide,

irr.-irregular,

diag.--diagonal,

tr.-trace.

Table II,

$\mathrm{P}=$ load in pounds,

$\mathrm{f}=$ load per sq. in., pounds,

$\mathrm{L}_{\mathrm{L}}=$ length between marks,

$\gamma=$ extension.

TABLE I

Aluminum-rich alloys

\begin{tabular}{|c|c|c|c|c|}
\hline \multicolumn{5}{|c|}{ o percent $\mathrm{Cu}$} \\
\hline $\begin{array}{c}\text { Heat } \\
\text { treatment }\end{array}$ & Diam. & $\begin{array}{l}\text { Ultimate } \\
\text { strength }\end{array}$ & $\begin{array}{l}\text { 'Percentage } \\
\text { extension }\end{array}$ & Fracture \\
\hline $\begin{array}{l}\text { A. . . . . } \\
\text { B, } 4 \text { days... }\end{array}$ & $\begin{array}{l}0.382 \\
0.398 \\
0.381 \\
0.375\end{array}$ & $\begin{array}{l}\text { I } 375^{\circ} \\
\text { I } 3320 \\
\text { I } 3130 \\
\text { I } 3400\end{array}$ & $\begin{array}{l}15.4 \\
17.0 \\
18.0 \\
18.0\end{array}$ & $\begin{array}{c}\text { G-f. cup, necked. } \\
" \\
" \\
\end{array}$ \\
\hline \multicolumn{5}{|c|}{5 percent $\mathrm{Cu}$} \\
\hline $\begin{array}{l}\text { B, } 4 \text { days. } . \\
B, 6 \text { days. }\end{array}$ & $\begin{array}{l}0.383 \\
0.399 \\
0.394 \\
0.376 \\
0.386 \\
0.376\end{array}$ & $\begin{array}{l}23750 \\
23780 \\
25750 \\
21050 \\
23620 \\
23200\end{array}$ & $\begin{array}{l}7 \cdot 5 \\
9.0 \\
6.4 \\
7.0 \\
8.6 \\
8.4\end{array}$ & $\begin{array}{l}\text { B-gr. cr. cup tr. slag } \\
\text { B-gr. cr. irr. tr. slag } \\
\text { G-gr. irr } \\
\text { G } \\
\text { G-f.cup } \\
\text { G-f. diag. }\end{array}$ \\
\hline
\end{tabular}


Table I-(Continued)

\begin{tabular}{|c|c|c|c|c|c|}
\hline \multicolumn{6}{|c|}{ Io percent $\mathrm{Cu}$} \\
\hline $\begin{array}{c}\text { Heat } \\
\text { treatment }\end{array}$ & Diam. & $\begin{array}{l}\text { Ultimate } \\
\text { strength }\end{array}$ & $\begin{array}{c}\text { Percentage } \\
\text { extension }\end{array}$ & Fracture & \\
\hline $\begin{array}{l}\text { A. ....... } \\
\text { B, } 4 \text { days... } \\
\text { B, } 3 \text { days. . }\end{array}$ & $\begin{array}{l}0.376 \\
0.376 \\
0.392 \\
0.380 \\
0.375 \\
0.374 \\
0.380 \\
0.377 \\
0.375\end{array}$ & $\begin{array}{l}29150 \\
28600 \\
27500 \\
26450 \\
21650 \\
23300 \\
2065^{\circ} \\
2175^{\circ} \\
22150\end{array}$ & $\begin{array}{l}\text { I. } 7 \\
\text { I. } 8 \\
\text { I. } 2 \\
2.0 \\
2.78 \\
2.8 \\
2.6 \\
2.86 \\
3.36\end{array}$ & $\begin{array}{c}\text { G-gr. st } \\
\text { B-tr. ox. } \\
\text { B-tr. ox. } \\
\text { G-gr. } \\
\text { G-gr. cr. irr. } \\
\text { " } \\
\text { " } \\
\text { " }\end{array}$ & \\
\hline \multicolumn{6}{|c|}{ I 5 percent $\mathrm{Cu}$} \\
\hline A. . . . . . & $\begin{array}{l}0.377 \\
0.380 \\
0.379 \\
0.374 \\
0.379 \\
0.378 \\
0.388 \\
0.377\end{array}$ & $\begin{array}{l}29300 \\
29200 \\
29700 \\
29550 \\
22550 \\
22500 \\
23600 \\
23000\end{array}$ & $\begin{array}{l}\text { I. } 4 \\
0.9 \\
0.9 \\
0.84 \\
\text { I. } \\
2.0 \\
2.0 \\
\text { I. } 9\end{array}$ & 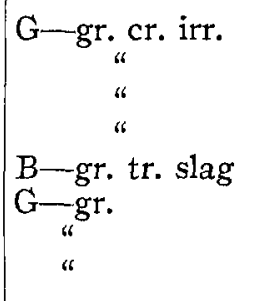 & \\
\hline
\end{tabular}

20 percent $\mathrm{Cu}$

\begin{tabular}{|c|c|c|c|c|}
\hline \multirow[t]{2}{*}{ A } & 0.376 & 32700 & O.I 5 & \multirow{3}{*}{$\begin{array}{c}\mathrm{G}-\mathrm{cr} \text {. seni-v. } \\
u\end{array}$} \\
\hline & 0.373 & 31050 & 0.4 & \\
\hline $\begin{array}{c}\text { (Test length, } \\
6 \text { inches) }\end{array}$ & 0.375 & 26950 & 0.5 & \\
\hline \multirow[t]{2}{*}{ B, 4 days... } & 0.379 & 22800 & I. I & $"$ \\
\hline & 0.379 & $2305^{\circ}$ & I. 2 & $"$ \\
\hline
\end{tabular}

25 percent $\mathrm{Cu}$

\begin{tabular}{|c|c|c|c|c|}
\hline A. . . . . . & $\begin{array}{l}0.377 \\
0.381 \\
0.381 \\
0.382\end{array}$ & $\begin{array}{l}r 7850 \\
18950 \\
20000 \\
22700\end{array}$ & $\begin{array}{l}0.14 \\
0.4 \\
\cdots \\
0.18\end{array}$ & $\begin{array}{c}\text { G-v. void } \\
\text { " } \\
\text { " }\end{array}$ \\
\hline $\mathrm{B}, 4$ days. . & $\begin{array}{l}0.379 \\
0.378\end{array}$ & $\begin{array}{l}25650 \\
13900\end{array}$ & $\begin{array}{c}0.6 \\
\ldots\end{array}$ & $\begin{array}{l}\mathrm{G}-\text { v. solid } \\
\mathrm{G}-\text { v. void }\end{array}$ \\
\hline
\end{tabular}


Table I-(Continued)

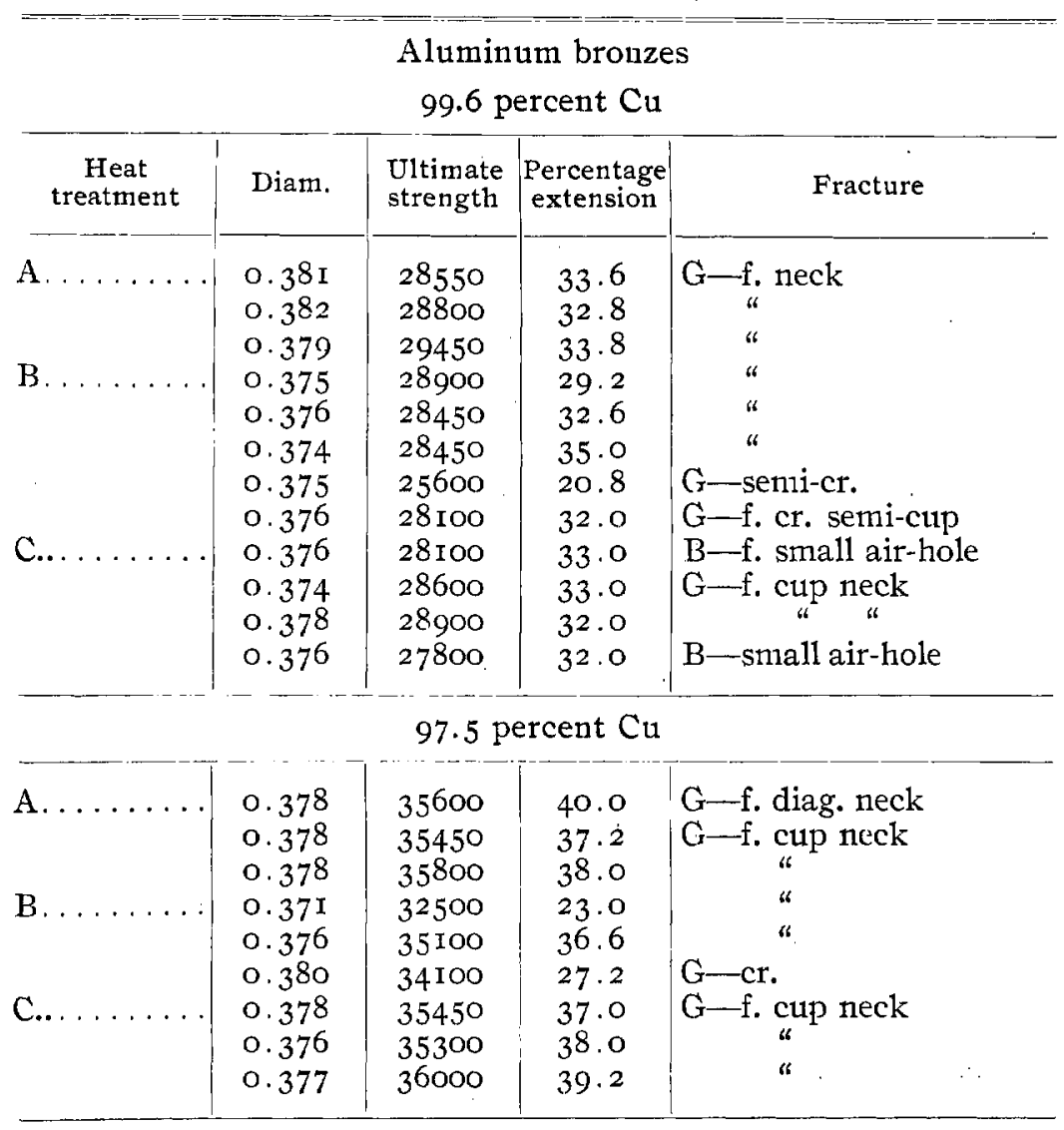

95 percent $\mathrm{Cu}$

\begin{tabular}{|c|c|c|c|c|}
\hline \multirow[t]{3}{*}{ A. } & $0.38 \mathrm{r}$ & 46850 & 56.6 & G-f. semi-cup neck \\
\hline & 0.377 & 46600 & 59.7 & \\
\hline & 0.375 & 45250 & 47.0 & B- " $"$ tr. slag \\
\hline \multirow[t]{4}{*}{ B. } & $0.37^{8}$ & 43000 & $57 \cdot 2$ & \\
\hline & 0.374 & 46250 & 46.4 & G-f. cr. cup neck \\
\hline & 0.377 & 47300 & $49 \cdot 6$ & B_- "small blow-hole \\
\hline & $\begin{array}{l}0.375 \\
0.378\end{array}$ & $\begin{array}{l}45250 \\
45750\end{array}$ & $\begin{array}{l}44.4 \\
54.4\end{array}$ & B- " tr. slag \\
\hline \multirow[t]{4}{*}{ C.. } & 0.377 & 47200 & 58.4 & G-f. diag. neck \\
\hline & 0.374 & 47000 & 60.8 & $G$-f. cup neck \\
\hline & 0.377 & $4765^{\circ}$ & 53.8 & \\
\hline & 0.375 & 47000 & $54 \cdot 4$ & “ \\
\hline
\end{tabular}


Table I-(Continued)

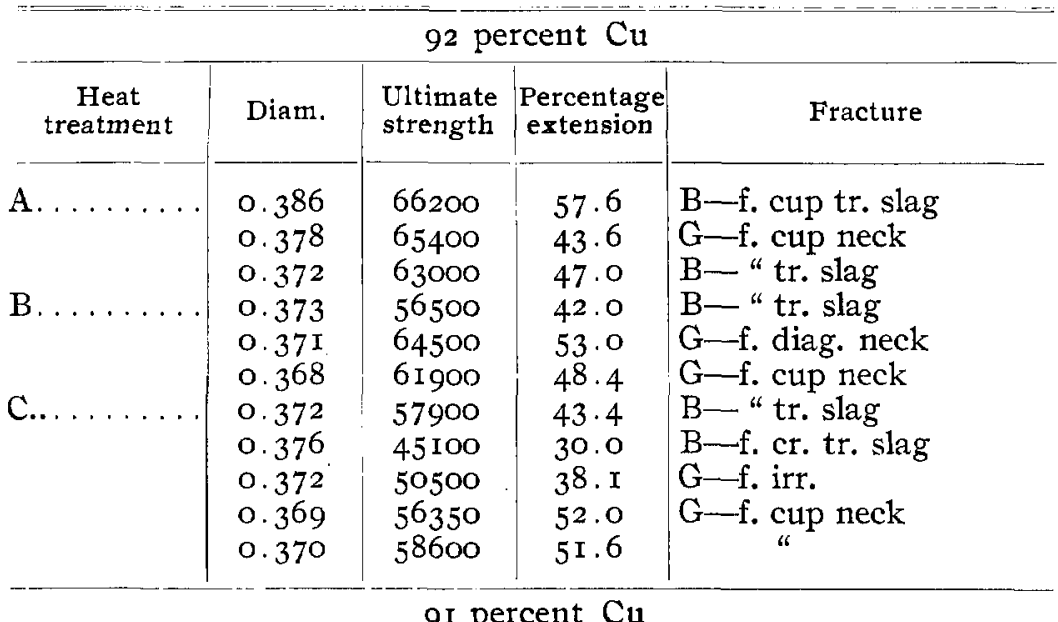

9I percent $\mathrm{Cu}$

\begin{tabular}{|c|c|c|c|c|}
\hline \multirow{4}{*}{ A. $\ldots \ldots \ldots$} & 0.372 & 84200 & 26.0 & B--gr. st. air-hole \\
\hline & 0.369 & $8 \mathrm{I} 800$ & I6.0 & $\mathrm{G}$-gr. st. \\
\hline & 0.372 & 86200 & I6. 2 & \\
\hline & 0.374 & 76100 & $25 \cdot 4$ & $B$ "tr. slag \\
\hline \multirow[t]{4}{*}{ B. } & 0.370 & $74 \mathrm{roO}$ & 24.0 & G-gr. st. \\
\hline & 0.372 & 73400 & $23 \cdot 4$ & \\
\hline & 0.376 & 67250 & 17.2 & $\mathrm{G}=$-cr. gr. \\
\hline & 0.374 & 69700 & I7.I & $"$ \\
\hline \multirow[t]{4}{*}{ C.......... } & 0.374 & 81000 & 24.2 & B-- " air hole \\
\hline & 0.375 & 74700 & 23.6 & $\mathrm{~B}-\mathrm{t}$ "tr. slag \\
\hline & 0.370 & 81800 & 30.0 & G-f. cr. \\
\hline & 0.369 & 83200 & 22.6 & “ \\
\hline \multirow[t]{2}{*}{$D \ldots \ldots \ldots$} & 0.372 & 74250 & 42.8 & “ \\
\hline & 0.373 & 74700 & $42 \cdot 4$ & " \\
\hline
\end{tabular}

90 percent $\mathrm{Cu}$

\begin{tabular}{|c|c|c|c|c|}
\hline \multirow[t]{3}{*}{ A......... } & 0.371 & 88000 & I.O & $\mathrm{G}=-\mathrm{cr}$. st. \\
\hline & 0.370 & 83700 & I. 2 & $"$ \\
\hline & 0.372 & 79200 & 6.4 & $"$ \\
\hline \multirow[t]{4}{*}{ B. } & 0.368 & 78700 & 5.6 & " \\
\hline & 0.365 & 72000 & 8.0 & $"$ \\
\hline & 0.374 & 73000 & 16.4 & " \\
\hline & 0.369 & 70100 & 7.2 & “ \\
\hline \multirow[t]{2}{*}{ C... } & 0.374 & 97500 & I. 2 & $\mathrm{G}$-cr. very irr. \\
\hline & 0.369 & 98000 & I. 3 & \\
\hline C.. & 0.363 & 98400 & I. 3 & G--cr. very irr. \\
\hline \multirow[t]{4}{*}{$D \ldots \ldots \ldots$} & 0.367 & 85900 & 18.4 & G--cr. irr. \\
\hline & $0.36 I$ & 86900 & 23.6 & " \\
\hline & 0.369 & 86800 & 20.4 & " \\
\hline & 0.369 & $8625^{\circ}$ & 18.8 & " \\
\hline
\end{tabular}


Table I-(Continued)

89 percent $\mathrm{Cu}$

\begin{tabular}{|c|c|c|c|c|}
\hline $\begin{array}{c}\text { Heat } \\
\text { treatment }\end{array}$ & Diam. & $\begin{array}{l}\text { Ultimate } \\
\text { strength }\end{array}$ & $\begin{array}{l}\text { Percentage } \\
\text { extension }\end{array}$ & Fracture \\
\hline \multirow[t]{3}{*}{ A. } & 0.374 & 83500 & I. 8 & \multirow{3}{*}{$\begin{array}{l}\text { B-coarsely cr. air hole } \\
\mathrm{G} \text {-coarsely cr. }\end{array}$} \\
\hline & 0.375 & 79600 & 2.0 & \\
\hline & 0.373 & 86900 & I. 8 & \\
\hline \multirow{3}{*}{ B } & 0.368 & 79800 & I. 2 & $"$ \\
\hline & $0.3^{80}$ & 59800 & 0.6 & " \\
\hline & $0.37 \mathrm{I}$ & 57700 & 0.6 & “ \\
\hline C... & 0.373 & 65700 & $\because$ & \multirow{2}{*}{$\mathrm{G}-\quad "$} \\
\hline & 0.372 & 55200 & 0.24 & \\
\hline
\end{tabular}

88 percent $\mathrm{Cu}$

\begin{tabular}{|c|c|c|c|c|}
\hline \multirow[t]{3}{*}{ A........ } & 0.371 & 78600 & I. 4 & $\mathrm{G}$-very coarsely cr. \\
\hline & 0.374 & 56200 & I. 2 & " \\
\hline & 0.372 & $4^{I} 45^{\circ}$ & 0.8 & $\mathrm{~B}-\approx$ bent \\
\hline \multirow[t]{4}{*}{ B. } & $0.37^{2}$ & $7135^{\circ}$ & 0.4 & $\mathrm{G}-\cdots$ \\
\hline & 0.371 & 64600 & 0.5 & \\
\hline & $0.37 I$ & 60100 & 0.5 & \\
\hline & 0.373 & 64000 & 0.3 & $"$ \\
\hline \multirow[t]{3}{*}{ C......... } & $0.37 \mathrm{I}$ & 23100. & I. 2 & $\begin{array}{c}\text { B-very large crystals, } \\
\text { bent }\end{array}$ \\
\hline & 0.368 & 37600 & I. 2 & These pieces showed \\
\hline & 0.372 & 29500 & I. 4 & $\begin{array}{l}\text { tracks developed in heat } \\
\text { treatment. }\end{array}$ \\
\hline
\end{tabular}

86 percent $\mathrm{Cu}$

\begin{tabular}{l|l|l|l|l}
\hline B $\ldots \ldots \ldots \ldots$ & 0.372 & 17300 & $\ldots$ & Vitreous \\
C.......... & 0.373 & 28800 & $\ldots$ & Vitreous
\end{tabular}

All the other pieces of this composition broke in the grips.

\begin{tabular}{l|l|l|l|l}
\hline \multicolumn{3}{c}{91.6 percent. $\mathrm{Cu}$} \\
\hline $\mathrm{C} . . . \ldots \ldots \ldots$ & 0.369 & 85500 & 27.5 & $\mathrm{G}$-gr. f. cr. \\
\hline
\end{tabular}

89.8 percent $\mathrm{Cu}$

\begin{tabular}{l|l|l|l|l}
\hline $\mathrm{A} \ldots \ldots \ldots$ & 0.370 & 108200 & 1.25 & $\mathrm{G}-\mathrm{cr}$ irr.
\end{tabular}


Tensile. Strengths of Copper Aluminum Alloys 483

TABLE II

Aluminum-rich Alloys

Aluminum-A, $d=0.382 \quad$ Aluminum-B, $d=0.375$

\begin{tabular}{|c|c|c|c|c|c|c|c|}
\hline$P$ & $f$ & $I_{1}$ & $\lambda$ & $P$ & $f$ & L & $\lambda$ \\
\hline 200 & $\mathrm{I} 750$ & 4.987 & o & 200 & 18 ro & 5.003 & 0 \\
\hline 400 & 3500 & $4.99 I$ & 0.004 & 400 & 3620 & 5.008 & 0.005 \\
\hline 600 & 5250 & 5.016 & 0.029 & 600 & 5430 & 5.037 & 0.034 \\
\hline 800 & 7000 & $5.06 \mathrm{I}$ & 0.074 & 800 & 7240 & 5.084 & $0.08 \mathrm{I}$ \\
\hline 1000 & 8750 & 5.118 & O.I3I & 1000 & 9050 & 5.132 & 0.129 \\
\hline I 300 & I I 350 & 5.266 & 0.279 & I 200 & 10860 & 5.231 & 0.228 \\
\hline 1460 & $1275^{\circ}$ & 5.457 & 0.470 & I 400 & I 2670 & $5 \cdot 440$ & 0.437 \\
\hline I 580 & $1375^{\circ}$ & 5.759 & 0.772 & I 480 & I 3400 & 5.90 & 0.897 \\
\hline
\end{tabular}

5 percent $\mathrm{Cu}-\mathrm{A}, d=0.394$

5 percent $\mathrm{Cu}-\mathrm{B}, d=0.386$

\begin{tabular}{|c|c|c|c|c|c|c|c|}
\hline 300 & 2460 & 5.000 & 0 & 300 & 2560 & 5,000 & 0 \\
\hline 600 & 4830 & 5.008 & 0.008 & 600 & $5 \mathrm{I} 30$ & 5.006 & 0.006 \\
\hline 900 & 7390 & $5.01 \mathrm{II}$ & O.OII & 900 & 7700 & $5.0 \mathrm{II}$ & 0.011 \\
\hline 1200 & 9850 & 5.014 & 0.014 & I 200 & II 350 & 5.038 & 0.038 \\
\hline I 500 & 12300 & $5.03 \mathrm{I}$ & 0.031 & I 400 & I 2000 & $5.06 \mathrm{I}$ & $0.06 \mathrm{I}$ \\
\hline I 800 & 14800 & 5.059 & 0.059 & 1600 & 13700 & 5.082 & 0.082 \\
\hline 2000 & 16400 & 5.084 & 0.084 & I 800 & I 5400 & 5. I I I & O.III \\
\hline 2200 & I8IOO & 5 II 2 & 0.112 & 2000 & 17100 & $5 \cdot 152$ & $0.15^{2}$ \\
\hline 2500 & 20500 & $5 \cdot 168$ & o. 168 & 2200 & 18800 & 5.200 & 0.200 \\
\hline 2800 & 23000 & 5.239 & 0.239 & 2400 & 20500 & 5.255 & 0.255 \\
\hline 3000 & 24600 & $5: 289$ & 0.289 & 2600 & 22200 & $5 \cdot 320$ & 0.320 \\
\hline 3120 & $2575^{\circ}$ & $5 \cdot 320$ & 0.320 & 2760 & 23600 & 5.430 & 0.430 \\
\hline
\end{tabular}

Io percent $\mathrm{Cu}-\mathrm{A}, d=0.376 \quad$ Io percent $\mathrm{Cu}-\mathrm{B}, d=0.374$

\begin{tabular}{r|r|r|r|r|r|r|r}
200 & 1800 & 5.000 & 0 & 300 & 2730 & 5.002 & 0 \\
600 & 5400 & 5.004 & 0.004 & 600 & 5460 & 5.006 & 0.004 \\
1000 & 9000 & 5.010 & 0.010 & 900 & 8190 & 5.012 & 0.010 \\
1200 & 10800 & 5.011 & 0.011 & 1200 & 10920 & 5.021 & 0.019 \\
1400 & 12600 & 5.013 & 0.013 & 1500 & 13650 & 5.039 & 0.037 \\
1600 & 14400 & 5.020 & 0.020 & 1800 & 16400 & 5.054 & 0.052 \\
1800 & 16200 & 5.028 & 0.028 & 2000 & 18200 & 5.070 & 0.068 \\
2000 & 18000 & 5.036 & 0.036 & 2200 & 20000 & 5.090 & 0.088 \\
2200 & 19800 & 5.049 & 0.049 & 2400 & 21850 & 5.117 & 0.115 \\
2400 & 21600 & 5.060 & 0.060 & 2500 & 22700 & 5.129 & 0.127 \\
3240 & 29150 & 5.120 & 0.120 & 2560 & 23300 & 5.140 & 0.138
\end{tabular}


Table II-(Continued)

\begin{tabular}{|c|c|c|c|c|c|c|c|}
\hline \multicolumn{4}{|c|}{ I 5 percent $\mathrm{Cu}-\mathrm{A}, d=0.379$} & \multicolumn{4}{|c|}{ I5 percent $\mathrm{Cu}-\mathrm{B}, d=0.388$} \\
\hline $\mathrm{P}$ & $f$ & L & $\lambda$ & $P$ & $f$ & L & $\lambda$ \\
\hline 300 & 2660 & 5.002 & o & 300 & 2540 & 5.002 & 0 \\
\hline 600 & 5320 & 5.005 & 0.003 & 900 & 76 & & 0.007 \\
\hline 900 & 7980 & 5.007 & 0.005 & 1200 & 10160 & & 0.018 \\
\hline I 500 & I 3300 & 5.012 & O.OIO & 1800 & I 5240 & 5.040 & 0.038 \\
\hline 2000 & I 7700 & 5.018 & 0.016 & 2000 & 171 & 50 & 0.048 \\
\hline 2500 & 22080 & 5.022 & 0.020 & 2200 & I 86 & & 0.057 \\
\hline 2700 & 23900 & 5.025 & 0.023 & 2400 & 203 & & 0.069 \\
\hline 3000 & 26600 & 5.030 & 0.028 & 2600 & 22050 & 5. & 0.084 \\
\hline $335^{\circ}$ & 29700 & 5.045 & 0.043 & 2800 & 23730 & 00 & 0.098 \\
\hline \multicolumn{4}{|c|}{20 percent $\mathrm{Cu}-\mathrm{A}, d=0.376$} & \multicolumn{4}{|c|}{20 percent $\mathrm{Cu}-\mathrm{B}, d=0.377$} \\
\hline 500 & 4500 & 5. & 0 & 5 & 4460 & IO & 0 \\
\hline IOOO & 9000 & 5.006 & 0.004 & Io & 8900 & & 0.004 \\
\hline I 500 & 13500 & 5.009 & 0.007 & I5 & I 3400 & & 0.012 \\
\hline 2000 & I 8000 & 5.012 & 0.010 & 2000 & I $785^{\circ}$ & & 0.032 \\
\hline 2500 & 22500 & 5.016 & $0.0 r_{4}$ & 2400 & $2 \mathrm{I} 400$ & & 0.049 \\
\hline 3640 & 32700 & 5. & $0.02 \mathrm{I}$ & $25^{80}$ & $23 c$ & & 0.050 \\
\hline \multicolumn{4}{|c|}{25 percent $\mathrm{Cu}-\mathrm{A}, d=0.381$} & \multicolumn{4}{|c|}{25 percent $\mathrm{Cu}-\mathrm{B}, d=0.379$} \\
\hline 500 & 4400 & 5 . & & 500 & 4400 & $\mathrm{O} 2$ & 0 \\
\hline IOOO & $875^{\circ}$ & & 0. & IO & $885^{\circ}$ & & 0.003 \\
\hline I 500 & I 3 I 40 & 5.020 & 0.010 & I5 & I 3250 & 5. & 0.009 \\
\hline 1800 & 16000 & 5.022 & 0.012 & I 800 & $1595^{\circ}$ & & 0.014 \\
\hline 2000 & 17500 & 5.025 & 0.01 & 2000 & 17700 & 5.020 & 0.018 \\
\hline \multirow[t]{4}{*}{2160} & $1895^{\circ}$ & 5.028 & o.018 & 2300 & 20350 & 5.023 & $0.02 \mathrm{I}$ \\
\hline & & & & 2500 & 22100 & 5.029 & 0.027 \\
\hline & & & & 2800 & 24600 & 5.032 & 0.030 \\
\hline & & & & 2900 & 25600 & 5.033 & $0.03 \mathrm{I}$ \\
\hline
\end{tabular}

Aluminum Bronzes

99.6 percent $\mathrm{Cu}-\mathrm{A}, d=0.379$

99.6 percent $\mathrm{Cu}-\mathrm{C}, d=0.378$

\begin{tabular}{r|r|r|r||r|r|r|r}
\hline 500 & 4420 & 5.020 & 0 & 500 & 4460 & 5.018 & 0 \\
1000 & 8840 & 5.130 & 0.110 & I000 & 8920 & 5.110 & 0.092 \\
1500 & 13280 & 5.230 & 0.210 & I500 & I3380 & 5.230 & 0.212 \\
2000 & 17680 & 5.410 & 0.390 & 2000 & r7840 & 5.400 & 0.382 \\
2500 & 22100 & 5.620 & 0.600 & 2400 & 21400 & 5.562 & 0.534 \\
2800 & 24800 & 5.790 & 0.770 & 2600 & 22300 & 5.662 & 0.644 \\
3000 & 26500 & 5.870 & 0.850 & 2800 & 25000 & 5.850 & 0.832 \\
3100 & 27400 & 6.050 & 1.030 & 3000 & 26800 & 5.972 & 0.954 \\
3200 & 28400 & 6.190 & I.110 & 3100 & 27700 & 6.060 & 1.042 \\
3300 & 29200 & 6.480 & I.460 & 3200 & 28600 & 6.260 & 1.242 \\
3320 & 29400 & 6.690 & 1.670 & 3250 & 29000 & 6.600 & 1.582
\end{tabular}


Tensile Strengths of Copper Aluminum Alloys 485 Table II-(Continued)

\begin{tabular}{c|r|r|r}
\hline \multicolumn{3}{c}{99.6 percent $\mathrm{Cu}-\mathrm{B}, d=0.375$} \\
\hline $\mathrm{P}$ & \multicolumn{1}{c|}{$f$} & $\mathrm{~L}$ & $\lambda$ \\
\hline 500 & 4525 & 5.010 & $\mathrm{O}$ \\
\hline I000 & 9050 & 5.058 & 0.048 \\
$\mathrm{I} 500$ & $\mathrm{I} 3575$ & 5.178 & 0.168 \\
$\mathrm{I} 800$ & 16300 & 5.278 & 0.268 \\
2000 & $\mathrm{I} 8100$ & 5.330 & 0.320 \\
2300 & 20800 & 5.550 & 0.530 \\
2500 & 22600 & 5.586 & 0.576 \\
2700 & 24400 & 5.700 & 0.690 \\
2900 & 26300 & 5.906 & 0.896 \\
3000 & 27200 & 6.025 & 1.015 \\
3100 & 28000 & 6.143 & $\mathrm{I} .133$ \\
3190 & 28900 & 6.460 & $\mathrm{I} .450$ \\
\hline
\end{tabular}

97.5 percent $\mathrm{Cu}-\mathrm{A}, d=0.378 \quad 97.5$ percent $\mathrm{Cu}-\mathrm{B}, d=0.376$

\begin{tabular}{l|c|c|c||c|c|c|c}
\hline I500 & I 3400 & 5.000 & 0 & I000 & 9000 & 5.04 & 0 \\
2000 & I 7850 & 5.150 & 0.150 & I 500 & I3500 & 5.120 & 0.080 \\
2500 & 22300 & 5.312 & 0.312 & 2000 & I 8000 & 5.300 & 0.260 \\
3000 & 26800 & 5.493 & 0.493 & 2500 & 22270 & 5.470 & 0.430 \\
3500 & 31200 & 5.770 & 0.770 & 3000 & 27000 & 5.660 & 0.620 \\
3800 & 33900 & 6.018 & 1.018 & 3500 & 31500 & 5.990 & 0.950 \\
4000 & 35700 & 6.370 & I.370 & 3750 & 34800 & 6.250 & 1.210 \\
4020 & 35900 & 6.900 & I.900 & 3890 & 35000 & 6.830 & 1.790 \\
\hline
\end{tabular}

97.5 percent $\mathrm{Cu}-\mathrm{C}, d=0.377$

\begin{tabular}{|c|c|c|c|}
\hline $\mathrm{P}$ & $f$ & L & $\lambda$ \\
\hline I 500 & $1345^{\circ}$ & 5.120 & o \\
\hline 3000 & 26880 & 5.650 & 0.530 \\
\hline 3500 & $3 \mathrm{I} 400$ & 5.710 & 0.590 \\
\hline $375^{\circ}$ & 33600 & 6.130 & I.OIO \\
\hline $\begin{array}{l}4000 \\
* \quad *\end{array}$ & $\begin{array}{c}35850 \\
*\end{array}$ & $6 \cdot 5^{20}$ & $\begin{array}{l}\mathrm{I} \cdot 400 \\
*\end{array}$ \\
\hline 1000 & 8930 & 6.629 & I. 503 \\
\hline 2000 & 17360 & 6.637 & I $: 5$ I 5 \\
\hline 3000 & 26790 & 6.640 & I. 520 \\
\hline 4000 & 35720 & 6.702 & I. 582 \\
\hline 4020 & 35900 & 6.960 & I. 840 \\
\hline
\end{tabular}


Table II-(Continued)

\begin{tabular}{|c|c|c|c|c|c|c|c|}
\hline \multicolumn{4}{|c|}{95 percent $\mathrm{Cu}-\mathrm{A}, d=0.3^{8 \mathrm{I}}$} & \multicolumn{4}{|c|}{95 percent $\mathrm{Cu}-\mathrm{B}, d=0.377$} \\
\hline $\mathbf{P}$ & $f$ & L & $\lambda$ & $\mathbf{P}$ & $f$ & $L$ & $\lambda$ \\
\hline IOOO & 8770 & 5.012 & 0 & IOOO & 8960 & 5.0 II & o \\
\hline I 300 & II 400 & 5.042 & 0.030 & I 500 & I 3440 & 5.060 & 0.049 \\
\hline 1600 & I 4030 & 5.130 & Q.II8 & 2000 & I 7920 & 5.290 & 0.279 \\
\hline 2000 & I 7540 & 5.282 & 0.270 & 2500 & 22400 & $5 \cdot 500$ & 0.489 \\
\hline 2500 & 21900 & $5 \cdot 495$ & 0.483 & 3000 & 26900 & 5.695 & 0.684 \\
\hline 3000 & 26300 & $5 \cdot 700$ & 0.688 & 3500 & 314.00 & $5 \cdot 908$ & 0.897 \\
\hline 3500 & 30700 & $5 \cdot 908$ & 0.896 & 4000 & $35^{800}$ & 6.198 & I. 187 \\
\hline 4000 & 35100 & 6.190 & I. 178 & 4500 & 40350 & 6.525 & I. 514 \\
\hline 450 & 39500 & 6.537 & I. 525 & 5000 & 44800 & 7.050 & 2.039 \\
\hline 5000 & 43800 & 7.070 & 2.058 & 5200 & 46600 & $7 \cdot 338$ & $2 \cdot 327$ \\
\hline${ }^{*}$ & * & 7.030 & 2.018 & 5280 & 47300 & $7 \cdot 480$ & 2.469 \\
\hline I000 & 8770 & 7.040 & 2.028 & \multicolumn{4}{|c|}{95 percent $\mathrm{Cu}-\mathrm{C}, d=0.377$} \\
\hline 2000 & I $754^{\circ}$ & 7.050 & 2.038 & & & & \\
\hline 3000 & 26300 & $7 \cdot 060$ & 2.048 & IOOO & 8960 & 5.010 & o \\
\hline 4000 & 35100 & 7.070 & $2.05^{8}$ & 2000 & 17920 & 5.270 & 0.260 \\
\hline 5000 & $43^{800}$ & 7.082 & 2.070 & 2500 & 22400 & 5.470 & 0.460 \\
\hline $5^{200}$ & 45500 & $7 \cdot 360$ & $2 \cdot 348$ & 3000 & 26900 & 5.670 & 0.660 \\
\hline \multirow[t]{8}{*}{5350} & 46900 & 7.830 & $2.8 \mathrm{I} 8$ & 3500 & $3 \mathbf{I} 400$ & 5.890 & 0.880 \\
\hline & & & & 4000 & $35^{800}$ & 6.190 & I. I 80 \\
\hline & & & & 4400 & 39400 & 6.470 & 1.460 \\
\hline & & & & 4800 & 43000 & 6. & I. $8 \mathrm{IO}$ \\
\hline & & & & 5000 & 44800 & 7.020 & 2.010 \\
\hline & & & & 5200 & 40000 & 7. & $2 \cdot 360$ \\
\hline & & & & 5300 & 47500 & & 2.680 \\
\hline & & & & 5320 & 470.50 & 7.750 & 2.740 \\
\hline \multicolumn{4}{|c|}{92 percent $\mathrm{Cu}-\mathrm{A}, d=0.386$} & \multicolumn{4}{|c|}{92 percent $\mathrm{Cu}-\mathrm{A}, d=0.37 \mathrm{I}$} \\
\hline 1000 & $855^{\circ}$ & 5.010 & o & IOOO & $925^{\circ}$ & 5.007 & o \\
\hline 2000 & I 7100 & 5.020 & O.OIO & 2000 & I 8500 & 5.016 & 0.009 \\
\hline 3000 & $25^{6} 5^{\circ}$ & $5 \cdot 100$ & 0.090 & 2500 & 23050 & 5.072 & 0.065 \\
\hline 3500 & 29900 & $5 \cdot 190$ & 0.180 & 3000 & 27750 & $5.19 I$ & 0.184 \\
\hline 4000 & 34200 & $5 \cdot 320$ & $0.3^{10}$ & 3500 & 32400 & $5 \cdot 340$ & 0.333 \\
\hline 4500 & 38400 & 5.450 & 0.440 & 4500 & 41600 & $5.7 \times 5$ & 0.780 \\
\hline 5000 & 42700 & $5 \cdot 575$ & $0.5^{65}$ & 5500 & 50800 & 6.160 & I. I 60 \\
\hline 5500 & 47000 & 5.710 & 0.700 & 6000 & 55500 & 6.430 & I. 423 \\
\hline 6000 & 5 I 300 & $5.8 \mathrm{zO}$ & 0.860 & $6_{5} 00$ & 60100 & 6.886 & I. 879 \\
\hline 6500 & $5555^{\circ}$ & 6.075 & I. 065 & 6800 & 62900 & 7.230 & 2.223 \\
\hline 7000 & 59800 & 6.310 & I. 300 & 6980 & 64500 & 7.650 & 2.643 \\
\hline 7500 & 64050 & 6.640 & 1.630 & & & & \\
\hline 7750 & 66200 & 6.880 & I. 870 & & & & \\
\hline
\end{tabular}


Table II-(Continued)

\begin{tabular}{|c|c|c|c|c|c|c|c|}
\hline \multicolumn{8}{|c|}{92 percent $\mathrm{Cu}-\mathrm{C}, d=0.370$} \\
\hline & & $\mathbf{P}$ & $f$ & $\mathbf{L}$ & \multicolumn{3}{|l|}{$\lambda$} \\
\hline & & 1000 & 9300 & 5.008 & \multicolumn{3}{|c|}{0} \\
\hline & & 2000 & 18600 & 5.048 & \multicolumn{3}{|c|}{0.040} \\
\hline & & 3000 & 27900 & $5 \cdot 400$ & \multicolumn{3}{|c|}{0.392} \\
\hline & & 3500 & 32500 & 5.630 & \multicolumn{3}{|c|}{0.622} \\
\hline & & 4000 & 37200 & 5.878 & \multicolumn{3}{|c|}{0.870} \\
\hline & & 4500 & 41800 & 6.160 & \multicolumn{3}{|c|}{ I. I 52} \\
\hline & & 5000 & 46500 & 6.310 & \multicolumn{3}{|c|}{ I.302 } \\
\hline & & 5500 & $5 \operatorname{II} 50$ & 6.620 & \multirow{2}{*}{\multicolumn{3}{|c|}{$\begin{array}{l}\text { I. } 6 \mathrm{I} 2 \\
\text { I. } 8 \mathrm{I} 2\end{array}$}} \\
\hline & & $575^{\circ}$ & 53500 & 6.820 & & & \\
\hline & & 6000 & 5.5800 & 7.007 & \multicolumn{3}{|c|}{ 1. 999} \\
\hline & & 6250 & $5^{8100}$ & 7.420 & \multicolumn{3}{|c|}{2.412} \\
\hline & & 6300 & 58500 & $7 \cdot 5^{80}$ & \multicolumn{3}{|c|}{2.572} \\
\hline \multicolumn{4}{|c|}{9 I percent $\mathrm{Cu}-\mathrm{A}, d=0.372$} & \multicolumn{4}{|c|}{91 percent $\mathrm{Cu}-\mathrm{A}, d=0.370$} \\
\hline 1000 & 9210 & 5.000 & 0 & IOOO & 9300 & 5.004 & 0 \\
\hline 2000 & I 8420 & 5.003 & 0.003 & 2000 & 18600 & 5.008 & 0.004 \\
\hline 3000 & 27630 & 5.015 & 0.015 & 3000 & 27900 & 5.020 & 0.016 \\
\hline 4000 & 36840 & 5.040 & 0.040 & 3500 & $3255^{\circ}$ & 5.040 & 0.036 \\
\hline 5000 & 46050 & $5 \cdot 100$ & 0.100 & 4000 & 37200 & 5.080 & 0.076 \\
\hline 6000 & 55260 & 5.200 & 0.200 & 4500 & 41800 & $5.15^{\circ}$ & 0.146 \\
\hline 6500 & 59800 & $5 \cdot 265$ & 0.265 & 5000 & 46500 & 5.225 & $0.22 \mathrm{I}$ \\
\hline 7000 & 64470 & $5 \cdot 350$ & 0.350 & 5500 & 5 I IOO & $5 \cdot 312$ & 0.308 \\
\hline 7500 & 69000 & $5 \cdot 420$ & 0.420 & 6000 & 55800 & $5 \cdot 470$ & 0.466 \\
\hline 8000 & 73500 & $5 \cdot 5^{20}$ & 0.520 & 6500 & 60500 & 5.612 & 0.608 \\
\hline 8500 & 78200 & 5.620 & $5 \cdot 620$ & 7000 & 65100 & $5 \cdot 790$ & 0.786 \\
\hline 9000 & 82800 & $5 \cdot 740$ & 0.720 & 7500 & 69750 & 6.015 & I.009 \\
\hline 9378 & 86400 & 5.8 IO & 0.810 & 7960 & 74000 & 6.200 & I. I 96 \\
\hline
\end{tabular}


Table II-(Continued)

\begin{tabular}{|c|c|c|c|c|c|c|c|}
\hline \multicolumn{4}{|c|}{91 percent $\mathrm{Cu}-\mathrm{C}, d=0.369$} & \multicolumn{4}{|c|}{$9 \mathrm{I}$ percent $\mathrm{Cu}-\mathrm{D}, d=0.372$} \\
\hline $\mathbf{P}$ & $f$ & $\mathbf{L}$ & $\lambda$ & $\mathrm{P}$ & $f$ & I & $\lambda$ \\
\hline 2000 & 18700 & 5.010 & o & 1000 & 9220 & 5.005 & 0 \\
\hline 3000 & $2805^{\circ}$ & 5.030 & 0.020 & 2000 & I 8400 & 5.010 & 0.005 \\
\hline 4000 & 37400 & 5.065 & 0.050 & 3000 & $27^{6} 50$ & $5 \cdot 100$ & 0.095 \\
\hline 4500 & 42060 & 5.110 & 0.100 & 4000 & 36900 & $5 \cdot 198$ & o. I93 \\
\hline 5000 & $4675^{\circ}$ & $5 \cdot I 65$ & O. I 55 & 5000 & 46100 & 5.410 & 0.405 \\
\hline 5500 & $5 \mathrm{I} 45^{\circ}$ & 5.275 & 0.265 & 6000 & 55300 & 5.680 & 0.675 \\
\hline 6000 & 56100 & $5 \cdot 330$ & 0.320 & 7000 & 64500 & 6.080 & I. 075 \\
\hline$*$ & $*$ & $\pi$ & * & 8000 & 73500 & 6.755 & I. $75^{\circ}$ \\
\hline IOOO & $935^{\circ}$ & $5 \cdot 457$ & 0.429 & 8180 & 74700 & $7 \cdot 120$ & 2 I I 5 \\
\hline 2000 & 18700 & $5 \cdot 439$ & 0.447 & & & & \\
\hline 3000 & 28050 & 5.464 & 0.454 & & & & \\
\hline 4000 & 37400 & $5 \cdot 470$ & 0.460 & & & & \\
\hline 5000 & $4675^{\circ}$ & $5 \cdot 474$ & 0.464 & & & & \\
\hline 6000 & $5^{6100}$ & $5 \cdot 480$ & 0.470 & & & & \\
\hline 7000 & 65450 & $5 \cdot 506$ & 0.496 & & & & \\
\hline 8000 & 74800 & $5 \cdot 730$ & 0.720 & & & & \\
\hline 8500 & 79500 & $5 \cdot 955$ & 0.945 & & & & \\
\hline 8900 & 83200 & 6.130 & I. I 20 & & & & \\
\hline \multicolumn{4}{|c|}{90 percent $\mathrm{Cu}-\mathrm{A}, d=0.37 \mathrm{I}$} & \multicolumn{4}{|c|}{90 percent $\mathrm{Cu}-\mathrm{B}, d=0.368$} \\
\hline 1000 & 9250 & 5.000 & o & 1000 & 9410 & 5.000 & 0 \\
\hline 2000 & 18500 & 5.001 & 0.001 & 2000 & I 8820 & $5.00 I$ & 0.001 \\
\hline 3000 & 27800 & 5.010 & 0.010 & 3000 & 28230 & 5.003 & 0.003 \\
\hline 4000 & 37000 & 5 .OI 5 & 0.015 & 4000 & 37640 & 5.010 & O.OIO \\
\hline 5000 & 46200 & 5.018 & 0.018 & 5000 & 47000 & 5.023 & 0.023 \\
\hline 6000 & 55500 & 5.020 & 0.020 & 6000 & 56460 & 5.070 & 0.070 \\
\hline 7000 & 64700 & 5.030 & 0.030 & 6500 & 61200 & 5.130 & 0.130 \\
\hline 8000 & 74000 & 5.040 & 0.040 & $75^{\circ} 00$ & 70500 & 5.210 & 0.210 \\
\hline 9000 & 83200 & 5.050 & 0.050 & 8000 & $75^{280}$ & $5 \cdot 260$ & 0.260 \\
\hline 9500 & 88000 & 5.060 & 0.060 & 8350 & 78500 & $5 \cdot 280$ & 0.280 \\
\hline \multicolumn{4}{|c|}{90 percent $\mathrm{Cu}-\mathrm{D}, d=0.36 \mathrm{I}$} & \multicolumn{4}{|c|}{90 percent $\mathrm{C} u-\mathrm{C}, d=0.3^{6} 3$} \\
\hline 2000 & 19560 & 5.010 & 0 & I000 & 9680 & $5.00 \mathrm{I}$ & 0 \\
\hline 3000 & 29340 & 5.020 & 0.010 & 3000 & I9360 & 5.009 & 0,008 \\
\hline 4000 & 39120 & 5.080 & 0.070 & 4000 & 38700 & 5.012 & O. OII \\
\hline 5000 & 48900 & 5.220 & 0.210 & 5000 & 49400 & 5.016 & 0.015 \\
\hline 6000 & 58680 & $5 \cdot 400$ & 0.390 & 6000 & 58700 & 5.025 & 0.024 \\
\hline 7000 & 68400 & 5.600 & 0.590 & 7000 & 67700 & $5.03 \mathrm{I}$ & 0.030 \\
\hline 8500 & 83100 & 6.060 & I.050 & 8000 & 77400 & 5.037 & 0.036 \\
\hline \multirow[t]{3}{*}{8900} & 87000 & 6.180 & I. I 7O & 9000 & 87000 & 5.043 & 0.042 \\
\hline & & & & 10000 & 96800 & 5.062 & 0.061 \\
\hline & & & & 10200 & 98560 & 5.066 & 0.065 \\
\hline
\end{tabular}


Tensile Strengths of Copper Aluminum Alloys 489 Table II-(Continued)

\begin{tabular}{l}
\multicolumn{2}{l}{89 percent $\mathrm{Cu}-\mathrm{A}, d=0.373$} \\
\hline $\mathrm{P}$
\end{tabular}

89 percent $\mathrm{Cu}-\mathrm{C}, d=0.372$

\begin{tabular}{c|c|c|c}
\hline $\mathrm{P}$ & $f$ & $\mathrm{~L}$ & $\lambda$ \\
\hline 2000 & 18400 & 5.000 & 0 \\
4000 & 36800 & 5.010 & 0.010 \\
6000 & 55200 & 5.012 & 0.012
\end{tabular}

88 percent $\mathrm{C} u-\mathrm{A}, d=0.37 \mathrm{I}$ 88 percent $\mathrm{Cu}-\mathrm{B}, d=0.372$

\begin{tabular}{l|c|c|c||c|c|c|c}
\hline 2000 & 18500 & 5.005 & 0 & 2000 & $I 8400$ & 5.002 & 0 \\
3000 & 27750 & 5.010 & 0.005 & 3000 & 27650 & 5.003 & 0.001 \\
4000 & 37000 & 5.017 & 0.012 & 4000 & 36800 & 5.008 & 0.006 \\
5000 & 46250 & 5.020 & 0.015 & 5000 & 46100 & 5.010 & 0.008 \\
6000 & 55500 & 5.030 & 0.025 & 6000 & 55300 & 5.013 & 0.011 \\
7000 & 64750 & 5.040 & 0.035 & 7000 & 64500 & 5.018 & 0.016 \\
8000 & 74000 & 5.070 & 0.065 & 7770 & 64800 & 5.020 & 0.018 \\
8500 & 78600 & 5.070 & 0.065 & & & & \\
\hline
\end{tabular}

88 percent $\mathrm{Cu}-\mathrm{C}, d=0.368$

\begin{tabular}{c|c|c|c}
$\mathrm{P}$ & $f$ & $\mathrm{~L}$ & $\lambda$ \\
\hline 2000 & $\mathrm{I} 8800$ & 5.028 & 0 \\
3000 & 28200 & 5.040 & 0.012 \\
4000 & 37600 & 5.060 & 0.032
\end{tabular}

Conclusions

In summing up the results of our investigations, we may draw the following conclusions:

I. In the aluminum-rich series the maximum dependable 
strength occurs in the neighborhood of the to per cent copper alloy and its value is about 28,000 pounds per square inch. The alloy is, however, of low ductility. 20 percent copper seems to be the greatest copper content for this series which will give a useful alloy.

2. Throughout the aluminum-rich series, annealing for from 3 to 6 days at $400^{\circ}$ reduces tensile strength and increases ductility.

3. In the bronzes with more than 92 percent copper, annealing seenis to have no marked effect on either strength or ductility.

4. In the bronzes, between 92 percent and 95 percent copper, tensile strengths varying from 48,000 to 66 ,000 pounds per square inch with ductilities of from 50 percent to 60 percent may be expected.

5. From 89-9I percent copper, annealing above $565^{\circ}$ and quenching in water gives an increased strength, but very low ductility.

6. Bronzes with less than 90 percent copper are brittle and likely to be unreliable; of coarse crystalline structure, and soft at temperatures considerably below the melting point.

7. Air-cooling bronzes of 90-9 I percent copper give an increased ductility with but slightly reduced strength.

8. The ductility of the chill-cast bronzes decreases very rapidly in the 9I percent copper content, the ductility in the 92 percent bronze being 50 percent to 60 percent and at 90 percent copper the ductility is only between 6 percent and 8 percent.

9. With go percent copper content a strength of 100,000 pounds per square inch may be expected from pieces chill-cast or annealed above $566^{\circ}$. The strength is considerably reduced by annealing below $566^{\circ}$.

Io. The $\beta$-alloys may be expected to give the highest strengths.

II. Snall amounts of the $\beta$-phase in contact with $a$ cause a very marked decrease in ductility and a very marked increase in strength. 
I2. Small amounts of the $\gamma$-phase in contact with $\alpha$ increases the strength and decreases the ductility of these alloys.

I3. The general effect of annealing is to decrease the ductility of the copper-rich alloy and to increase the ductility of the aluminum-rich alloys.

I4. The most dependable high-strength aluninum-rich alloy is found near the edge of the $\eta$-field or with a Io percent copper content.

15. The maximum tensile strength does not occur at a boundary curve.

The expense of this work has been covered by a grant from the Carnegie Institution to Prof. Bancroft.

The testing has been done in the laboratories of Sibley College.

This research has been conducted under the direction of Prof. Bancroft, and we wish here to thank him for his assistance and kindly criticisms.

Comell University 